\title{
Recent warming in the Balearic Sea and Spanish Mediterranean coast. Towards an earlier and longer summer
}

\author{
MARÍA JOSÉ LÓPEZ GARCÍA \\ Departament de Geografia, Universitat de València, Av. Blasco Ibáñez 28, 46010 Valencia, España \\ E-mail: maria.j.lopez@uv.es
}

Received: March 20, 2014; accepted: May 18, 2015

\begin{abstract}
RESUMEN
Este trabajo analiza los cambios recientes en la temperatura del mar Balear y las tierras costeras circundantes. Para el análisis de la temperatura terrestre se han utilizado registros mensuales de varios observatorios litorales en el contorno de la cuenca Balear en el periodo 1960-2010, y para el análisis de la temperatura superficial del mar (SST, por sus siglas en inglés) se utilizaron imágenes térmicas mensuales de satélite procedentes del Physical Oceanography Distributed Active Archive Center (PO.DAAC) disponibles para el periodo 1985-2009. Se observa un incremento de la temperatura desde finales de la década de 1980, especialmente notable en los últimos 25 años, con tasas de $0.039^{\circ} \mathrm{C} /$ año en tierra para el periodo $1960-2010$ y $0.026^{\circ} \mathrm{C} /$ año para el mar durante el periodo 1985-2009. El análisis estacional de las tendencias muestra que en los últimos 25 años las mayores tasas de calentamiento se producen durante la transición primavera-verano, con tasas máximas en el mes de junio $\left(0.12^{\circ} \mathrm{C} /\right.$ año en tierra y $0.08^{\circ} \mathrm{C} /$ año en el mar). Los resultados evidencian una tendencia hacia el adelantamiento y prolongación de la estación estival en las últimas décadas, tanto en tierra como en mar.
\end{abstract}

\begin{abstract}
This paper analyses recent changes in the temperature of the Balearic Sea and surrounding coastal areas. Monthly temperature data from several weather stations located around the Balearic basin have been used to obtain land temperatures during the period 1960-2010, and monthly thermal satellite images from the Physical Oceanography Distributed Active Archive Center (PO.DAAC) covering the period 1985-2009 have been processed to obtain sea surface temperatures (SSTs) in the Balearic Sea. A rise in temperature has been observed since 1980 and increasingly in the last 25 years, with an average warming trend of $0.039^{\circ} \mathrm{C} /$ year on land for the period 1960-2010 and $0.026^{\circ} \mathrm{C} /$ year in SSTs for 1985-2009. The seasonal analysis showed that, in the last 25 years, higher trends were registered during the transition from spring to summer, with the highest warming rates in June $\left(0.12{ }^{\circ} \mathrm{C} /\right.$ year on land and $0.08{ }^{\circ} \mathrm{C} /$ year in SSTs). Results show a recent tendency towards earlier and longer summers both on land and sea.
\end{abstract}

Keywords: Air temperature, sea surface temperature, global warming, Mediterranean Sea, Balearic Sea, temperature trends, seasonal and temporal variability.

\section{Introduction}

At the present time there seems to be a reasonable consensus among the scientific community about the increase in global average air temperature during the 20th century, especially during the last three decades. The IPCC Fourth Assessment Report (AR4) gives a rate of warming in land temperatures for the Northern Hemisphere ranging from 0.072 to $0.089^{\circ} \mathrm{C} /$ decade during the period 1901-2005 (IPCC, 2007). Although there is some disagreement as to whether this warming is due to climate variability or climate change, numerous studies confirm the global warming on regional, continental and global scales in the last decades (Easterling et al., 1997; Jones et al., 1999; Jones and Moberg, 2003). However, different rates are given depending on the spatial scale 
(global, regional or local), the geographical area and the period of time considered.

The Mediterranean has been identified as one of the "hot-spots" in future climate change projections because it is an especially vulnerable environment (Giorgi, 2006; Lionello et al., 2006; Giorgi and Lionello, 2008; Lejeusne et al., 2010). There are many factors behind this assertion: (1) it is a transitional region between mid-latitudes and subtropical climate regimes; (2) it is dominated by the Mediterranean Sea, a semi-enclosed sea which is an important source of moisture and a heat reservoir, that has also been considered as a miniature ocean by physical, chemical, climatic and environmental studies (Bethoux et al., 1999); and (3) the Mediterranean environment has experienced a strong human impact since ancient times due to demographic pressure, agricultural exploitation, urbanization and, more recently, coastal tourism. Many works (Bethoux et al., 1990, 1998; Rholin and Bryden, 1992; Vargas-Yáñez et al., 2005, 2008, 2010) confirm the increase in temperature in deep, intermediate and surface Mediterranean waters, and others explore the effects of this warming in the biology and ecology of organisms in the sea (see the review by Lejeusne et al., 2010) as well as its role in fisheries fluctuations (Tzanatos et al., 2014). It is important to further increase our knowledge of regional, seasonal and decadal variability on temperatures in the Mediterranean environment as temperature changes interact with pollution, overfishing, sea level changes or acidification, and can trigger major changes in the ecosystems.

In the Iberian Peninsula, during the last two decades, many papers have been published which attempt to explain the spatial and temporal variability of temperature at national, regional or local level. Most studies agree that there has been an increase in temperature from the 1970s onward (Esteban-Parra et al., 1995, 2003; Serra et al., 2001; Morales et al., 2005; Salat and Pascual, 2006; Brunet et al., 2007; Homar et al., 2010; Del Río et al., 2011; El Kenawy et al.; 2012). Amongst them, we highlight those that explore the monthly, seasonal and annual variability of the warming trends. In their study of temperatures in Castilla-León (Spain) for the period 1945-1996, Morales et al. (2005) found significant positive trends only in winter, but when analyzing a shorter and more recent series (1972-1995) they obtained a clear increasing trend for the spring $\left(0.058^{\circ} \mathrm{C} /\right.$ year $)$ and summer $\left(0.057^{\circ} \mathrm{C} /\right.$ year $)$. Del Río et al. (2011), using data from 473 weather stations distributed all over Spain for the period 1961-2006, observed a significant positive trend at national scale with rates of $0.1-0.2^{\circ} \mathrm{C} / \mathrm{decade}$. They also found that summer and spring are the seasons with the largest contributions to annual trends, with rates of $0.3{ }^{\circ} \mathrm{C} /$ decade, and a maximum rate recorded in June (around $0.5^{\circ} \mathrm{C} /$ decade). Similar results can be inferred from Brunet et al. (2007), also covering the whole of Spain and based on 22 weather stations for the period 1850-2005. These authors obtained a warming rate of $0.1{ }^{\circ} \mathrm{C} /$ decade for the whole period and indicated that autumn and winter contributed slightly more than spring and summer to the annual warming over the 1850-2005 period. However, a detailed reading of this work shows that for the most recent decades, between 1973-2005, the highest warming rates are in spring $\left(0.77{ }^{\circ} \mathrm{C} /\right.$ decade $)$ and summer $\left(0.67{ }^{\circ} \mathrm{C} /\right.$ decade $)$. More recently, El Kenawy et al. (2012), in a study about variability of temperature over northeastern Spain (the region between the Pyrenees and the Iberian system) based on data from 19 weather stations for the period 1920-2006, obtained warming rates of $0.1^{\circ} \mathrm{C} /$ decade and pointed out that the warming observed during this period was mainly due to the increase of temperature from the 1970s. A deeper analysis based on 128 stations for the period 1960-2006 led them to the conclusion that the warming is faster during the warm-half of the year (spring and summer) than in the cold-half (winter and autumn) and that coastal areas have warmed at higher rates than inland areas. A maximum warming trend of $0.22{ }^{\circ} \mathrm{C} /$ decade was obtained in summer for the period 1920-2006, and a maximum of $0.66{ }^{\circ} \mathrm{C} /$ decade in spring when the period considered was restricted to 1960-2006.

This idea of a larger increase of temperature during the warm seasons had previously been pointed out by other authors. In a study based on the analysis of the climatic series of air and sea surface temperature (SST) of the oceanographic station L'Estartit, located on the Catalan coast (Spain), for the period 1974-2005, Salat and Pascual (2006) obtained mean rates of $0.6^{\circ} \mathrm{C} /$ decade and $0.3{ }^{\circ} \mathrm{C} /$ decade for air temperature and SST, respectively, with the highest trend in air temperature $\left(+0.8^{\circ} \mathrm{C} /\right.$ decade $)$ observed for the period April-June. The impression that the higher warming rates observed in recent decades are due to 
the increase of temperature during spring and summer seems to be spreading in scientific literature, and is leading to many studies which explore seasonal and monthly temperature variability. Similar conclusions have also been found recently in other Mediterranean regions like Tuscany (central Italy), where Bartolini et al. (2012) observed, for the period 1955-2007, a positive trend for mean temperature of about $0.9^{\circ} \mathrm{C}$ in 50 years with larger increases in summer and spring compared to a smaller positive trend in autumn and winter. In the eastern Mediterranean, Dahech and Beltrando (2012) reported a significant increasing trend of annual average daily maximum and minimum temperatures in the city of Sfax (Tunisia) since the 1980s, especially during the warm season. Also Scherrer et al. (2008) found larger changes in mean temperature during the summer in a study of central Europe for the period 1961-2005. It is not yet possible to know if this tendency will continue or if it is only a consequence of climate variability, but observations seem to confirm the hypothesis that in Mediterranean areas we are moving towards a longer and earlier summer.

In a previous work (López García and Camarasa, 2011) we described the regional, seasonal and decadal variability of SST in the western Mediterranean basins from the analysis of monthly thermal satellite images for the period 1985-2007. This study showed an annual warming trend of $0.3{ }^{\circ} \mathrm{C} / \mathrm{decade}$, with the largest significant trend $\left(0.6{ }^{\circ} \mathrm{C} /\right.$ decade $)$ during the oceanographic spring season (from April to June). Although the series was limited by the availability of thermal images to only 23 years, these images allowed the study to cover most of the western basins of the Mediterranean (Alboran, Algerian, Balearic and northern basins). The paper suggested an early warming of the sea in all basins during the oceanographic spring (April, May and June), with an increase of $0.5-1{ }^{\circ} \mathrm{C}$ in the mean SST over the two decades studied.

The aim of the present paper is to increase our knowledge of the recent warming observed in Mediterranean areas during the spring and summer and to discern more precisely the time of the year when the largest increases and significant warming trends are observed. We analyze SST around the Balearic Sea as well as land temperature in the surrounding area. Monthly mean temperature at several coastal weather stations covering the period 1960-2010 have been se- lected for the study of land temperature, and monthly thermal satellite images for the period 1985-2009 have been processed to study SST trends. Finally, we wanted to test whether the results obtained in our previous study of SST in the western Mediterranean (López García and Camarasa, 2011) are in agreement with land temperature trends.

\section{Data set and methods}

\subsection{Study area and database}

The study area covers the Balearic Sea and its surroundings (Fig. 1). Although the Balearic Sea extends from the Spanish coast to the Balearic Islands, this work considers a wider area extending to Corsica and Sardinia, a zone considered a transition space between the northern and the Algerian basins. In this area, the recent Atlantic water that occupies the Algerian basin coming through the Strait of Gibraltar meets the older and cooler modified Atlantic water circulating from the Ligurian Sea towards the south along the Iberian continental shelf. These water mass-

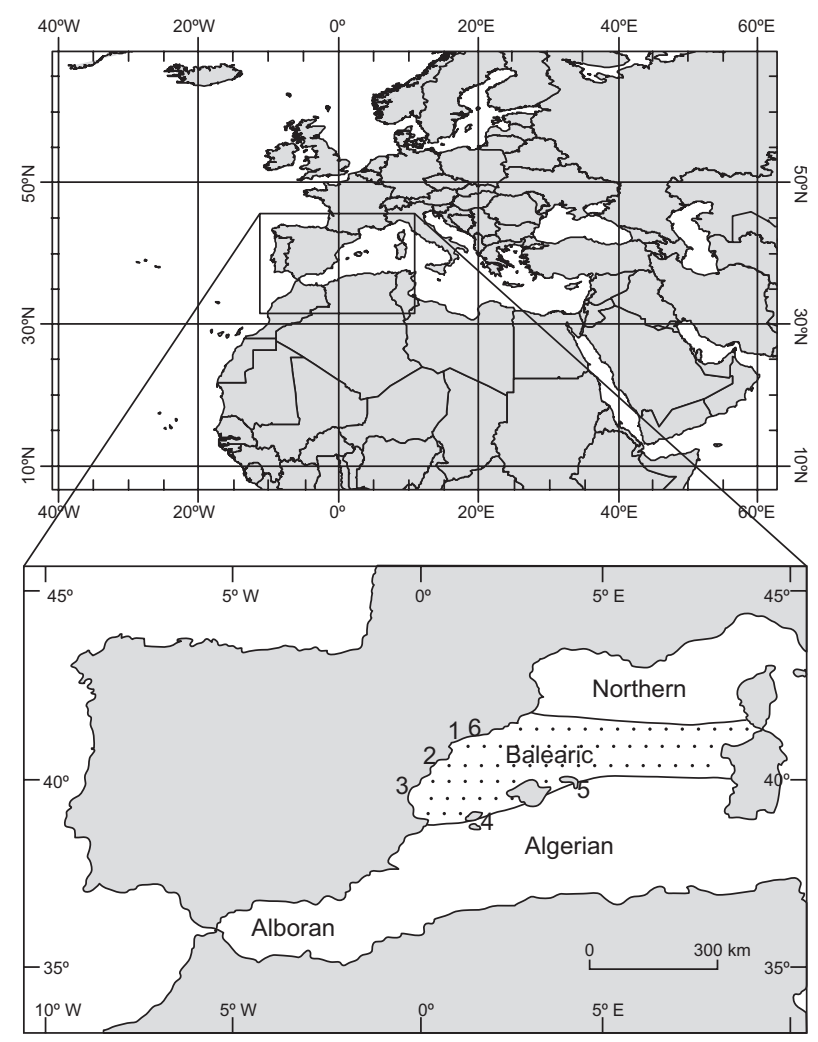

Fig. 1. Map of the study area. The land stations and the grid points used to compute average values in the Balearic Sea are shown. 
es form the Balearic front, whose position around the Balearic Islands varies through the year (López García, 1991; López García et al., 1994; Millot, 1999). A previous study of the seasonal and spatial variability in the western Mediterranean basins from thermal satellite images (López García and Camarasa, 2011) confirmed this transitional character. The Balearic Sea has the highest annual thermal amplitude of all the basins $\left(11.8^{\circ} \mathrm{C}\right)$ with the lowest temperature in February $\left(13.5^{\circ} \mathrm{C}\right)$ under the influence of the coolest waters of the northern basin and the highest temperature in August $\left(25.3{ }^{\circ} \mathrm{C}\right)$ with similar values to those registered in the Algerian basin, where the warmest waters of the western Mediterranean are found in spring and summer.

In our analysis, SST data have been derived from thermal images of the satellite NOAA AVHRR. The data were obtained from the Physical Oceanography Distributed Active Archive Center at the NASA Jet Propulsion Laboratory, Pasadena, CA. The Center provides the Pathfinder SST dataset which is the longest time series of historical global datasets currently available online (http://podaac. jpl.nasa.gov/). We have used the $4 \mathrm{~km}$ Pathfinder version 5 SST Project (Pathfinder V5), which provided several products for 5, 7, and 8-day, as well as monthly and yearly temporal averages (see Vázquez et al., 1998; Kilpatrick et al., 2001). Our study is based on monthly images which we consider a robust product for climatological analysis of SST because daily or weekly data contain many missing information due to the cloud cover in the images. Only nighttime data were selected to avoid the effect of intense diurnal heating which can be very important in the Mediterranean during the spring and summer (Deschamps and Frouin, 1984). A total of 300 images were collected covering the period 1985-2009 for a subset of the Mediterranean Sea comprising the area between $27-49^{\circ} \mathrm{N}$ and $14^{\circ} \mathrm{W}-14^{\circ} \mathrm{E}$. The images were processed by using the GIS software Idrisi 32 in order to obtain averaged monthly temperature values for the Balearic Sea applying a regular sampling of 59 points (one point for every 0.5 degrees of latitude and longitude). Figure 1 shows the area of study and the sampling points. In order to estimate SST values an algorithm is used whose coefficients are continuously updated. This makes the data suitable for studying multi-year SST trends. A validation of
AVHRR Pathfinder SST over the Mediterranean Sea using independent data obtained from MEDATLAS CTD and XBT casts was done by D'Ortenzio et al. (2000), who found a mean bias of $0.2^{\circ} \mathrm{C}$, and Marullo et al. (2007), who evaluated Pathfinder by comparing satellite SSTs to in situ data from 1985 to 2005, concluding that satellite data are able to reproduce in situ measurements with a mean bias of less than $0.1 \mathrm{~K}$ and a root-mean-square error (RMSE) of about $0.5 \mathrm{~K}$. A more detailed description of the methodology can be found in López García and Camarasa (2011).

Land temperatures were obtained from six coastal weather stations covering the period 1960-2010: Valencia-airport, Tortosa, Barcelona-airport, Barcelona-Fabra, Ibiza- airport and Menorca- airport. The choice of these stations was made taking into account the length of the series and their location away from urban areas in order to avoid "heat island" effects on the records (Fig. 1). All the data come from the Agencia Española de Meteorología (Spanish Meteorological State Agency, AEMET) with the exception of the refined series of the Fabra observatory. Table I shows the specific location characteristics of the weather stations. All the airport weather stations in Spain renewed their instruments and were relocated during the years 2003-2005. The availability of a parallel series of data for the Valencia airport at both the old and new locations for the period 2005-2010 allowed us to detect a bias of $-1.20^{\circ} \mathrm{C}$ on average for the data collected in the new location, which let us adjust the series. However, since the other relocated airport stations (Barcelona, Ibiza and Menorca) have no parallel series, their data were only used in a preliminary trend analysis but not included in the final calculations of trends in order to avoid the effects of these discontinuities. In order to be consistent with the analysis of SST, mean monthly values have also been used in the analysis of land temperatures.

\subsection{Trend analysis}

The statistical analysis was performed by using the software Prism. Simple linear regressions have been applied to the time series, calculating averaged annual trends for the whole period and monthly trends. A 12-month moving average has been applied to monthly data to smooth out the inter-annual variability and remove seasonal fluctuations. The slope of the least squared regression was used for indicating the magnitude of change during the period analyzed. 


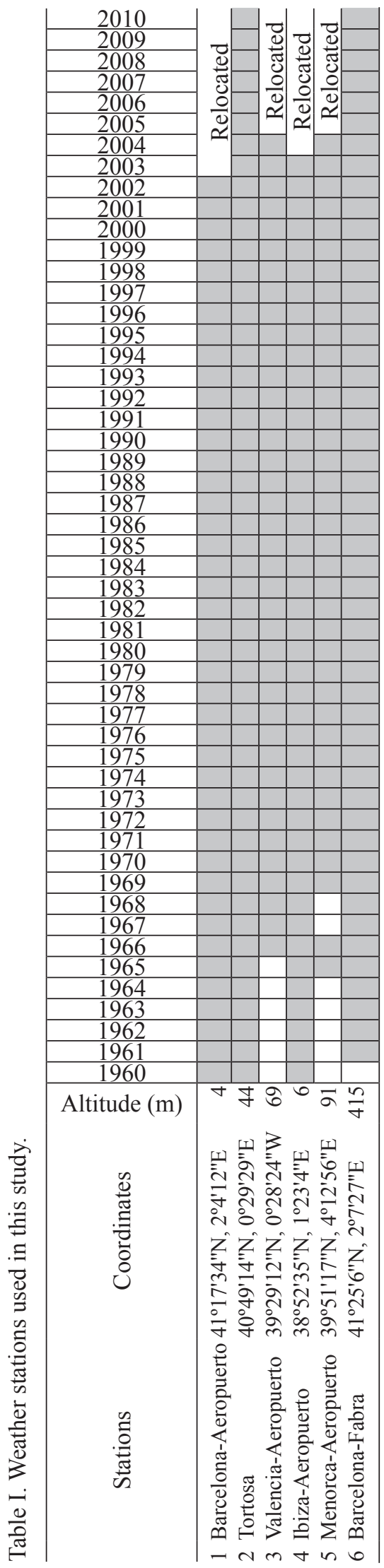

The trend was expressed in units of ${ }^{\circ} \mathrm{C}$ per year. The statistical significance at the $95 \%$ confidence level was tested by the standard $t$-test.

\section{Results}

In this section we present together the trends obtained for land and sea surface temperatures in the study area considering first the interannual variability and then seasonal and monthly trends.

\subsection{Interannual trends}

The linear trend in mean temperature was assessed separately for every land station for the period 19602010. Figure 2 shows the evolution curves obtained. Differences in magnitude are due to the specific location of the station, however all the stations in general showed a similar evolution, with an apparent warming trend especially noticeable from the 1980 s. Lower values were registered in the stations of Barcelona airport and Fabra which are located further north and, the latter, at 415 masl.

In order to obtain an averaged value representative of the area, we selected three stations with the best quality data and cover of temperature ranges: Valencia-airport (3), Tortosa (2) and Barcelona-Fabra (6), and calculated an averaged new series. The Pearson correlation coefficient between these series is 0.99 . As mentioned above, the stations located at airports $(1,4,5)$ were relocated between 2003 and 2005 leading to discontinuity in the data. Our correlations of the data series from the different stations were all high to date (0.98-0.99), so we took the Valencia, Tortosa and Barcelona-Fabra data as representative of the whole region and we discarded the rest. Figure 3 shows both the evolution curve obtained for SST in the Balearic Sea (1985-2009) and the averaged evolution curve obtained for land temperatures in the three stations selected, for the longer series 1960-2010. Monthly data have been plotted and a 12-month moving average applied to remove seasonal effects. The correlation between land and SST series shows a coefficient of 0.85 . The slope of the linear regressions indicates an increase trend of $0.026{ }^{\circ} \mathrm{C} /$ year for SST and a rate of $0.039^{\circ} \mathrm{C} /$ year for land temperature, all significant at $95 \%$ confidence intervals. The rate for land stations remains very much the same $\left(0.038{ }^{\circ} \mathrm{C} /\right.$ year $)$ when the shorter series of years (1985-2009) is considered. The visual observation of the curves suggests that the increase of temperature is stronger in the 


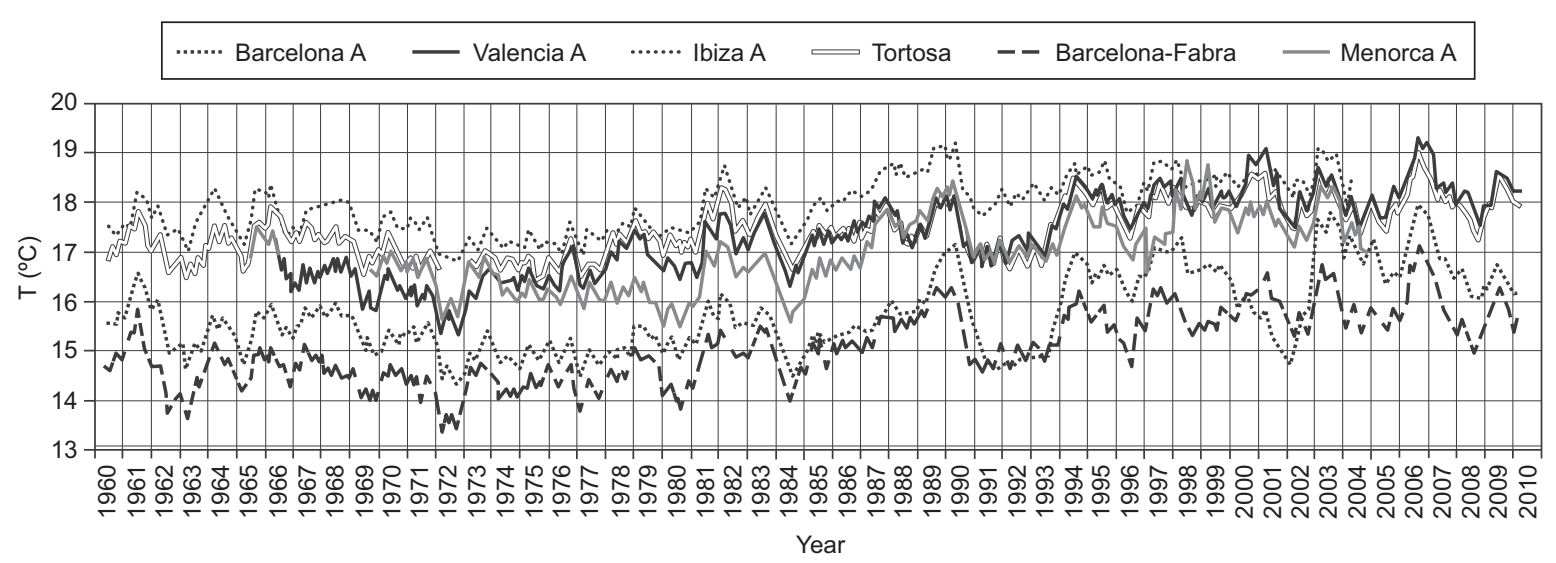

Fig. 2. Interannual temperature variability at the six weather stations. Monthly data are plotted and a 12-month moving average applied to eliminate seasonal effects.

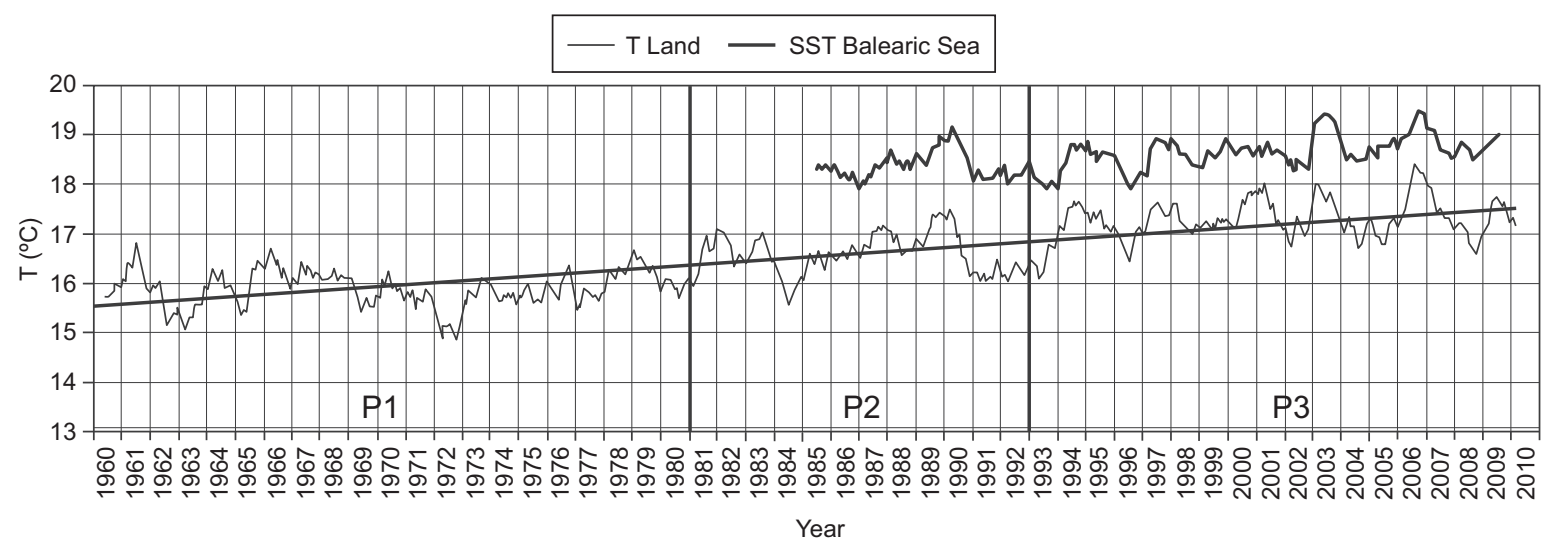

Fig. 3. Interannual temperature variability for land (average values of three weather stations) (1960-2010) and for SST (averaged value over the whole Balearic Sea) (1985-2009). Monthly data have been plotted and a 12-month moving average applied to eliminate seasonal effects. The time range in SST is limited to the number of years available. P1, P2 and P3 are the time periods used in Figures 5 and 6.

1980s decade, the warm summers of 1990, 2003 and 2006 being clearly visible. These results seem to be in agreement with the observations of other authors (Morales et al., 2005; Del Río et al., 2011; El Kenawy et al., 2012) in several regions of Spain.

\subsection{Monthly and seasonal trends}

Monthly trends were calculated using linear regression in order to assess their seasonal contribution to the average annual warming rate. Trends were obtained for the series of years available, but, in order to better compare land and sea temperatures, the trends for land stations were also calculated for the period 19852009 when data were available for the sea. Table II shows the monthly rates obtained in each period, with their statistical significance. For land stations on the period 1960-2010, all trends - except February - are significant and the maximum warming rates (over $0.05^{\circ} \mathrm{C} /$ year) are registered in the warmest months of August, June, and July. However, when the analysis is limited to the most recent 25 years, the maximum trends - for land and sea — are obtained during spring and the beginning of summer, especially in June, when a maximum warming rate of $0.12^{\circ} \mathrm{C} /$ year has been recorded in land temperatures and $0.08^{\circ} \mathrm{C} /$ year in SSTs. For this period, only the data for April, May, and June are significant for land and April, May, June and July for SST. These peak records in June have also been obtained by other authors in the Mediterranean basin, with a significant maximum rate of $0.12{ }^{\circ} \mathrm{C} /$ year in June recorded for the northern basin during the period 1985-2009 (López García and 
Table II. Monthly and annual trends $\left({ }^{\circ} \mathrm{C} /\right.$ year $)$ for coastal stations (T Land) and sea surface temperatures (SSTs). Significant values at the $95 \%$ confidence level are marked in bold.

\begin{tabular}{lccc}
\hline & \multicolumn{2}{c}{ T Land } & SST \\
& $1960-2010$ & $1985-2009$ & $1985-2009$ \\
\hline January & $\mathbf{0 . 0 2 5}$ & 0.068 & 0.013 \\
February & 0.025 & 0.006 & 0.011 \\
March & $\mathbf{0 . 0 4 6}$ & 0.039 & 0.019 \\
April & $\mathbf{0 . 0 3 3}$ & $\mathbf{0 . 0 7 2}$ & $\mathbf{0 . 0 4 3}$ \\
May & $\mathbf{0 . 0 3 9}$ & $\mathbf{0 . 0 7 9}$ & $\mathbf{0 . 0 6 0}$ \\
June & $\mathbf{0 . 0 5 7}$ & $\mathbf{0 . 1 2 3}$ & $\mathbf{0 . 0 7 7}$ \\
July & $\mathbf{0 . 0 5 0}$ & 0.041 & $\mathbf{0 . 0 5 6}$ \\
August & $\mathbf{0 . 0 5 9}$ & 0.027 & 0.028 \\
September & $\mathbf{0 . 0 2 9}$ & -0.009 & 0.010 \\
October & $\mathbf{0 . 0 3 9}$ & 0.053 & 0.002 \\
November & $\mathbf{0 . 0 2 8}$ & 0.025 & 0.010 \\
December & $\mathbf{0 . 0 2 7}$ & -0.014 & 0.017 \\
Annual & $\mathbf{0 . 0 3 9}$ & $\mathbf{0 . 0 3 8}$ & $\mathbf{0 . 0 2 6}$ \\
\hline
\end{tabular}

Camarasa, 2011) and rates of $0.16^{\circ} \mathrm{C} /$ year in June for the Tyrrhenian, Ligurian and Adriatic seas during the period 1985-2006 (Nykjaer, 2009).

Figure 4 jointly represents monthly trends obtained for land and sea. In Figure 4a land data show the trends for the whole period (1960-2010) while in Figure 4b only the trends for the more recent and shorter series (1985-2009) are shown. The horizontal lines point out the annual trend in each case. If we observe the trends for land stations during the longer series (Fig. 4a), the highest contribution to the annual trend corresponds to summer (August, June, July), however, if we observe the data for the more recent decades (Fig. 4b), a more similar pattern is found for SST and the coastal land stations with the highest contribution in June. Autumn and winter show the lowest trends and these data are not statistically significant. The anomalous high rate $\left(0.068^{\circ} \mathrm{C} /\right.$ year $)$ registered in January on land stations can be explained by a widespread frost episode which occurred at the beginning of the series in 1985.

The results show that, during the last 25 years, temperature in June has increased around $2{ }^{\circ} \mathrm{C}$ in the Balearic Sea and about $3{ }^{\circ} \mathrm{C}$ at the coastal land stations. These increases have also been marked during May, July and April while the trends are not significant for autumn and winter months. Consequently, the annual warming rate observed during the last decades seems to be mainly due to the increase of temperature occurring during the transition period from
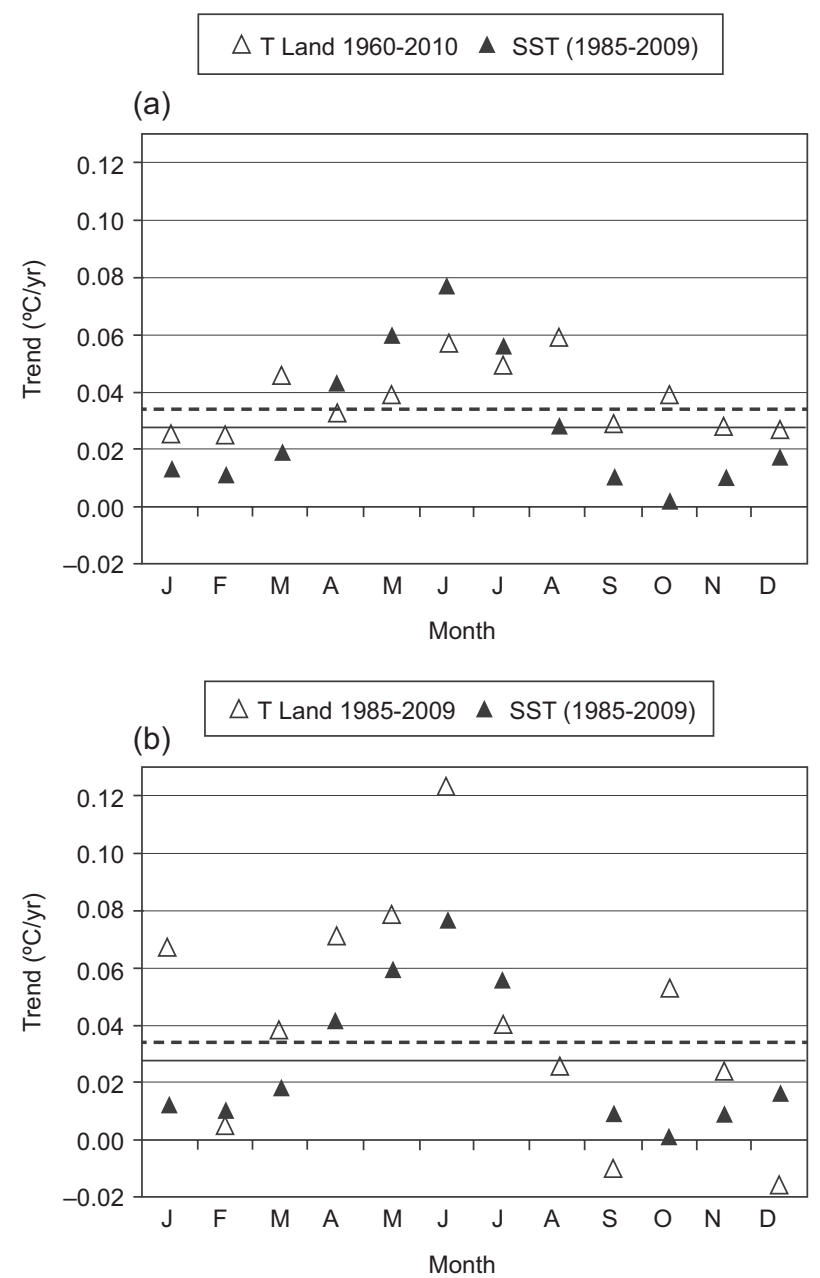

Fig. 4. Linear trends $\left({ }^{\circ} \mathrm{C} /\right.$ year $)$ for every month for land and SST. The horizontal lines represent the averaged annual trend in land (dashed line) and sea (solid line). (a) Land temperature trends have been calculated for the series 1960-2010. (b) Land and SST trends have been calculated for 1985-2009.

spring to summer, being June the most critical month. In other words, in the Balearic basin and Spanish Mediterranean it seems that summer is beginning earlier than a few decades ago.

Although the length of the series, especially for the sea, is not very long, we tried to identify possible changes in the seasonal cycle over the period of time studied. From the visual observation of interannual evolution curves in Figure 3, we divided the series in three periods: Period 1 (P1), from 1960 to 1980; Period 2 (P2), from 1981 to 1992; and Period 3 (P3), from 1993 to 2010. For each period, monthly mean temperatures were calculated and seasonal curves 
(a)

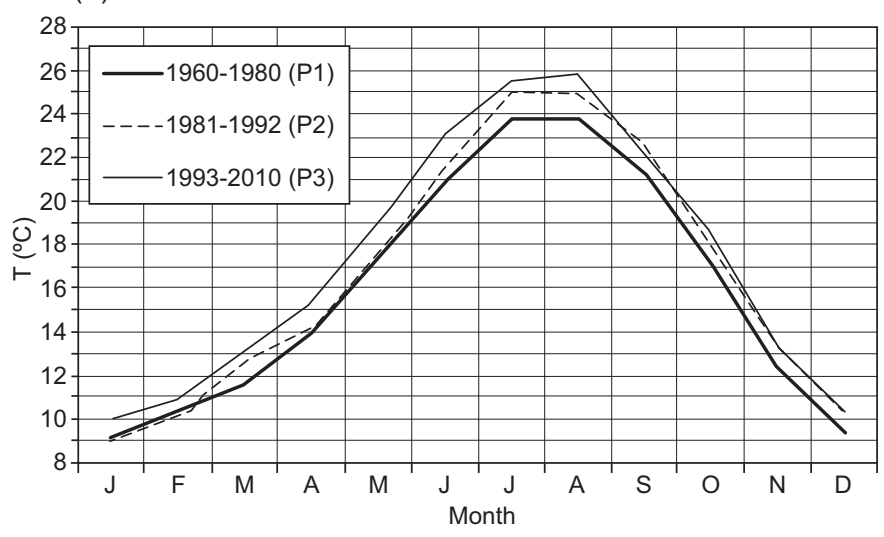

(b)

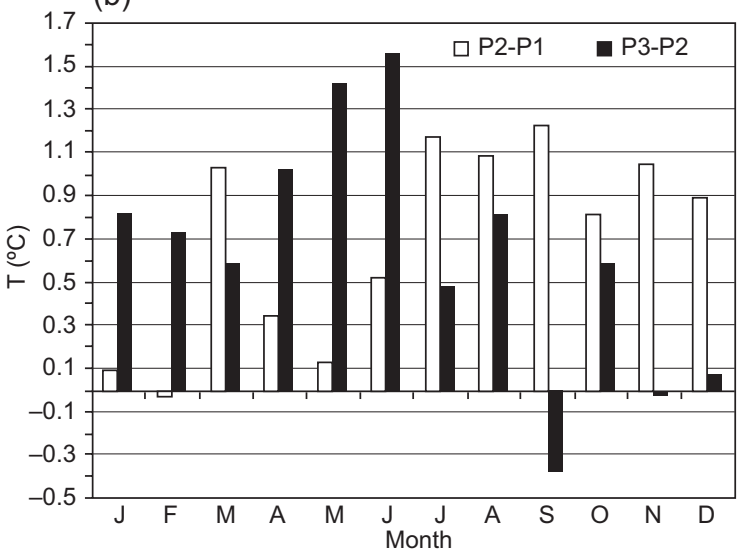

Fig. 5. (a) Changes in the seasonal cycle for land temperatures (average values of three weather stations) calculated in three time periods. (b) Absolute difference of monthly temperatures between each period.

were drawn for land (Fig. 5a) and SST (Fig. 6a). The absolute differences $\left({ }^{\circ} \mathrm{C}\right)$ obtained for every month between the average temperatures in each period are also represented in Figures $5 \mathrm{~b}$ and $6 \mathrm{~b}$ for land and sea, respectively.

For land stations (Fig. 5a, b) we can observe an increase of about $1{ }^{\circ} \mathrm{C}$ from P1 (1960-80) to P2 (19811992) during the summer and autumn and also in March. During the most recent decade, from P2 (1981-1992) to P3 (1993-2010), however, the strongest increase in temperature is registered during late spring-summer, with the highest values of $1.6^{\circ} \mathrm{C}$ in June, $1.4^{\circ} \mathrm{C}$ in May, and $1^{\circ} \mathrm{C}$ in April. There is also an increase above $0.5^{\circ} \mathrm{C}$ in January, February, March, August and October. Overall, for the whole period, adding up the changes of
P2-P1 and P3-P2, the highest increases were registered in June and August (about $2{ }^{\circ} \mathrm{C}$ ).

In the Balearic Sea (Fig, 6a, b), due to the limited series of data available, it was only possible to compare the seasonal curves from P2 (1985-92) to P3 (1993-2009). During this period, the strongest increase in temperature is registered during June and May, with values of about $1{ }^{\circ} \mathrm{C}$. The increase of $0.5{ }^{\circ} \mathrm{C}$ observed during winter on land stations is not observed at sea, where the recent warming is produced clearly during the oceanographic spring (April, May and June). Both on land and at sea during the last decade there seems to be a slight decrease of temperature in September, which is also noticeable in October at sea. (a)

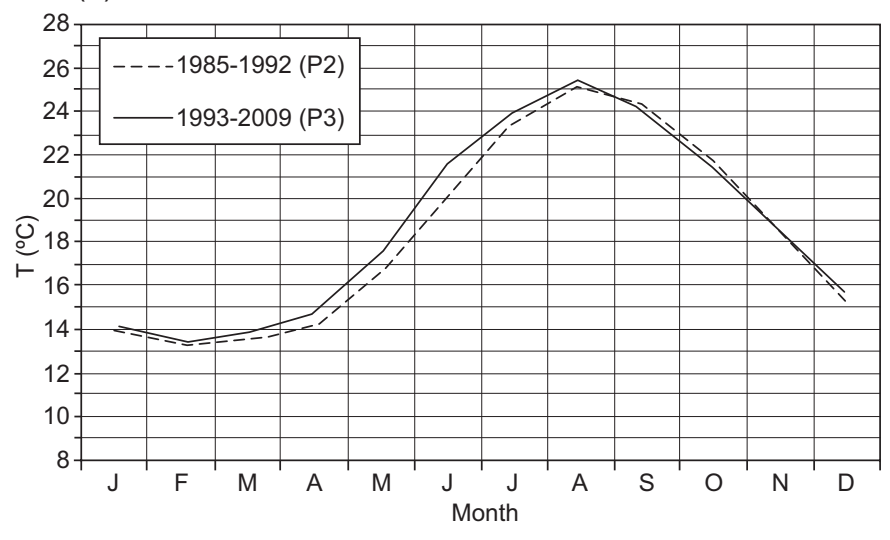

(b)

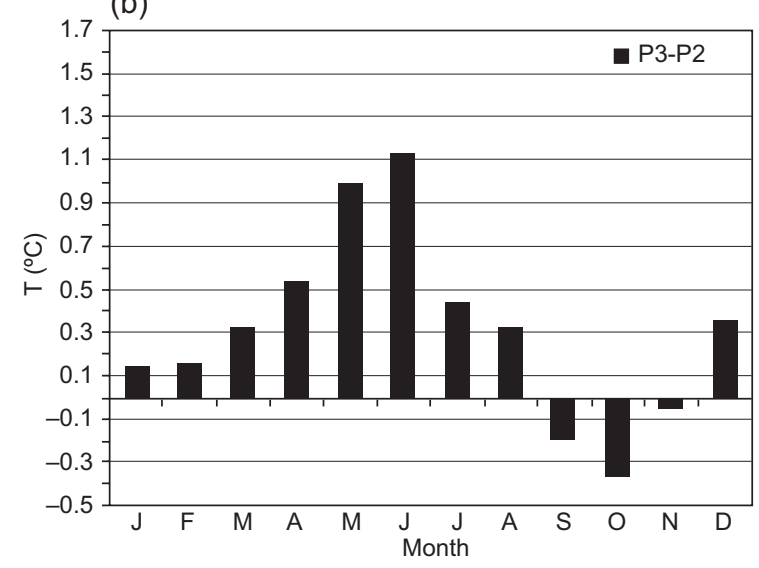

Fig. 6. (a) Changes in the seasonal cycle for SSTs in the Balearic Sea calculated for two time periods. (b) Absolute difference of monthly temperatures between the two periods. 


\section{Discussion and conclusions}

This paper describes the recent annual and monthly evolution of temperature in the Balearic Sea and the surrounding Spanish Mediterranean coastal area from SST satellite-derived data and in situ land temperature records. Similar behavior has been observed for land and sea temperatures. The analysis of land temperature for the period 1960-2010 shows a warming rate of $0.039^{\circ} \mathrm{C} /$ year, representing an overall increase of $1.9^{\circ} \mathrm{C}$ during the last 50 years. This rate is consistent with the trend obtained for the SST, where a lower rate $\left(0.026^{\circ} \mathrm{C} /\right.$ year $)$ has been registered for the period 1985-2009, which translates into an overall increase of $0.7^{\circ} \mathrm{C}$ in 25 years. The annual warming rate in SST is in agreement with the findings of Nykjaer (2009), López García and Camarasa (2011) and Skliris (2012) for the western Mediterranean, who gave a rate of about $0.03{ }^{\circ} \mathrm{C} /$ year for about the same period; and with the trends given by Macías et al. (2013) for the whole Mediterranean $\left(0.037{ }^{\circ} \mathrm{C} /\right.$ year $)$. Although the warming of the climate system since the middle of the 19th century is accepted by almost all scientists, the observed trends in oceanic SST differ depending on the ocean, the period of reference and also the database employed in the analysis. It is not easy to estimate long-term warming in the world's oceans as they do not warm uniformly and decadal changes in ocean circulation can mask warming signals. However, several works have tried to estimate long-term warming at a global scale. Rayner et al. (2006), based on the improved International Comprehensive Ocean-Atmosphere Data Set (ICOADS) observed linear warming between 1850 and 2004 of $0.52 \pm 0.19^{\circ} \mathrm{C}$ ( $95 \%$ confidence interval) for the globe, a bit higher $\left(0.59 \pm 0.20^{\circ} \mathrm{C}\right)$ for the Northern Hemisphere, and lower $\left(0.46 \pm 0.29^{\circ} \mathrm{C}\right.$ for the Southern Hemisphere. At a regional scale, some studies suggest that the warming is particularly marked in the Atlantic Ocean (Palmer et al., 2007; Servain et al., 2014). The latter indicates a clear warming of the entire tropical Atlantic Ocean from 1975 , with positive trends $\left(>1^{\circ} \mathrm{C}\right)$ in some areas in the last 50 years.

In the Mediterranean Sea, a semi-enclosed sea connected to the Atlantic Ocean through the Strait of Gibraltar, the warming seems to be happening at a higher rate than in the open ocean. Our results for the Balearic Sea agree with others who have observed a marked warming of the Mediterranean Sea in the last three decades (Skliris et al., 2012) and are consistent with their hypothesis that the warming of the western Mediterranean could be induced by the warming of the Atlantic inflow related to the Atlantic Multidecadal Oscillation (AMO) (Macías et al., 2013) combined with increasing concentrations of greenhouse gases produced by human activities. Macías et al. (2013) concluded that $58 \%$ of the recent warming in Mediterranean waters could be attributed to the AMO oscillation, whilst anthropogenic-induced climate change was only responsible for $42 \%$ of the total trend. The acceleration of the warming observed in the Mediterranean during the 1990s could be caused, according to them, by a superimposition of anthropogenic-induced warming with the positive phase of the AMO. According to their projections, a slowdown of the warming trend will happen in the coming decades.

Our analysis of seasonal trends in the Balearic basin has shown important differences in trends, depending on the time of the year. During the last 25 years, both land temperature and SST have registered the highest warming rates during the transition from spring to summer, with a maximum rate in June of $0.12{ }^{\circ} \mathrm{C} /$ year on land and $0.08{ }^{\circ} \mathrm{C} /$ year at sea. According to these records, on average, the temperature in June has increased by $3{ }^{\circ} \mathrm{C}$ on land and $2{ }^{\circ} \mathrm{C}$ in the Balearic Sea over the period. When the study is extended to a longer period (1960-2010) at land stations, maximum rates are registered in June and also in August with a trend of $0.06{ }^{\circ} \mathrm{C} /$ year for both months. These land temperature results are consistent with those studies which indicate that warming observed in recent decades is mainly due to the increase of temperatures during the warm seasons, either spring or summer (Morales et al., 2005; Brunet et al., 2007; Del Río et al., 2011; Bartolini et al., 2012; El Kenawy et al., 2012). However, our data indicate that the warming takes place precisely during the transition from spring to summer with June being the month when the largest changes have been recorded especially during the last three decades.

Del Río et al. (2011), using data from 473 weather stations distributed all over Spain also found maximum warming rates in June with a trend of $0.5{ }^{\circ} \mathrm{C} /$ decade for the period 1961-2006. With respect to SST, Skliris et al. (2012) also found much higher warming rates during spring/summer than autumn/ winter in their seasonal analysis of the Mediterranean basin based on satellite-derived temperature. 
They observed large seasonal variability in the western Mediterranean, where the highest warming rate was in spring $\left(0.054^{\circ} \mathrm{C} /\right.$ year $)$ and then summer $\left(0.029^{\circ} \mathrm{C} /\right.$ year $)$, with almost zero warming in autumn. They performed the analysis using two datasets: 24 years of satellite derived temperature, and 35 years of in situ data (NOCS V.2), finding similar patterns from both datasets over the common period, although lower trends were obtained from the NOCS data. Unfortunately, they do not report monthly rates which would allow comparison with our results.

In our study, the observation of changes in seasonal curves over different periods show that in land, where a longer series of data is available, there was an increase of temperature $>1.5^{\circ} \mathrm{C}$ between the earlier period (1960-1980) and the more recent period (19932010). However, once again these changes show seasonal differences. Between the periods 1960-80 and 1981-1992 the increase of temperature occurred mainly during the summer and autumn (from July to December), but between the more recent periods, from 1981-1992 to 1993-2010, the increase is especially strong in spring (May and June). Overall, these results confirm the trend towards an earlier onset of the summer in the last two decades as observed in the Mediterranean Sea basins from the analysis of thermal images (López García and Camarasa, 2011). The analysis of both SST and air temperature for land stations located near the Spanish Mediterranean coast also indicates that June is the month when the highest increase of temperature is registered. This result suggests the importance of seasonal and monthly analysis in global warming studies as annual trends can smooth over seasonal differences.

The changes in observed seasonal cycles could be important due to their ecological implications. In a review of climate change effects on the Mediterranean, Lejeusne et al. (2010) warn about the effects of fauna shifting, the spread of invasive species, the risk of what some authors have called the "tropicalization" of the Mediterranean (Bianchi, 2007), as well as the possibility of more multispecies mass mortality events such as those related to heat waves in 1999 and 2003. These authors point out the need for further research to better understand the implications of climate change on Mediterranean marine ecosystems. They also note that a multidisciplinary approach would be the only way to tackle such a complex problem. In this context the changes in the seasonal cycle observed in this paper and the effect of earlier and longer summers on the ecosystem deserve consideration.

\section{Acknowledgments}

The author wishes to acknowledge the Physical Oceanography Distributed Active Archive Center (PO.DAAC) at NASA Jet Propulsion Laboratory, California (USA) for providing the SST data used in the study. Also the Spanish Meteorological State Agency (AEMET) for providing the temperature database, especially to the people of the Valencia territorial delegation (Drs. J. Tamayo and J. A. Núñez). Professor J. M. Raso Nadal from the University of Barcelona is also acknowledged for kindly making the Fabra station database available.

\section{References}

Bartolini G., V. di Stefano, G. Maracchi and S. Orlandini, 2012. Mediterranean warming is especially due to summer season. Evidences from Tuscany (central Italy). Theor. Appl. Climatol. 107, 279-295, doi:10.1007/ s00704-011-0481-1.

Bethoux J. P., B. Gentilli, J. Raunet and D. Tailliez, 1990. Warming trends in the Western Mediterranean deep waters. Nature 347, 660-662.

Bethoux J. P., B. Gentilli and D. Taillie, 1998. Warming and freshwater budget change in the Mediterranean since the 1940s. Their possible relation to the green house effect. Geophys. Res. Lett. 25, 1023-1026, doi:10.1029/98GL00724

Bethoux J. P., B. Gentili, P. Morin, E. Nicolas, C. Pierre and D. Ruiz-Pino, 1999. The Mediterranean Sea: A miniature ocean for climatic and environmental studies and a key for the climatic functioning of the North Atlantic. Progr. Oceanogr. 44, 131-146.

Bianchi C. N., 2007. Biodiversity issues for the forthcoming tropical Mediterranean Sea. Hydrobiologia 580, 7-21, doi:10.1007/s10750-006-0469-5.

Brunet M., P. D. Jones, J. Sigro, O. Saladie, E. Aguilar, A. Moberg, P. M. Della-Marta, D. Lister, A. Walther and D. López, 2007. Temporal and spatial temperature variability and change over Spain during 18502005. J. Geophys. Res. 112, D12117, doi:10.1029/ 2006JD008249.

Dahech S. and G. Beltrando, 2012. Observed temperature evolution in the City of Sfax (Middle Eastern Tunisia) for the period 1950-2007. Climatic Change 114, 689706, doi:10.1007/s10584-012-0420-x. 
Del Río S., L. Herrero, C. Pinto-Gomes and A. Penas, 2011. Spatial analysis of mean temperature trends in Spain over the period 1961-2006. Global Planet. Change 78, 65-75, doi:10.1016/j.gloplacha.2011.05.012.

Deschamps P.Y. and R. Frouin, 1984. Large diurnal heating of the sea surface observed by the HCMR experiment. J. Phys. Oceanogr. 14, 177-184.

D'Ortenzio F., S. Marullo and R. Santoreli, 2000. Validation of AVHRR Pathfinder SST's over the Mediterranean Sea. Geophys. Res. Lett. 27, 241-244.

El Kenawy A., J. L. López-Moreno and S. M. Vicente-Serrano, 2012. Trend and variability of surface air temperature in northeastern Spain (1920-2006): Linkage to atmospheric circulation. Atmos. Res. 106, 159-180, doi:10.1016/j.atmosres.2011.12.006

Easterling D. R., B. Horton, P. D. Jones, T. C. Peterson, R. R. Karl, D. E. Parker, M. J. Salinger, V. Razuvayev, N. Plummer, P. Jamason and C. K. Folland, 1997. Maximum and minimum temperature trends for the globe. Science 277, 364-367, doi:10.1126/ science.277.5324.364.

Esteban-Parra M. J., F. S. Rodrigo and Y. Castro-Díez, 1995. Temperature trends and change points in the northern Spanish Plateau during the last 100 years. Int. J. Climatol. 15, 1031-1042, doi:10.1002/ joc.3370150909.

Esteban-Parra M. J., D. Pozo-Vázquez, F. S. Rodrigo and Y. Castro-Diez, 2003. Temperature and precipitation variability and trends in northern Spain in the context of the Iberian Peninsula climate. In: Mediterranean climate variability and trends (H. J. Bolle, Ed.). Springer, Berlin, 259-276.

Homar V., C. Ramis, R. Romero and S. Alonso, 2010. Recent trends in temperature and precipitation over the Balearic Islands (Spain). Climatic Change 98, 199-211. Giorgi F., 2006. Climate change hot-spots. Geophys. Res. Lett. 33, L08707, doi:10.1029/2006GL025734.

Giorgi F. and P. Lionello, 2008. Climate change projections for the Mediterranean region. Global Planet. Change 63, 90-104, doi:10.1016/j.gloplacha.2007.09.005.

IPCC, 2007. Climate Change 2007: The Physical Science

Basis. Contribution of Working Group I to the Fourth Assessment Report of the Intergovernmental Panel on Climate Change (S. Solomon, D. Qin, M. Manning, Z. Chen, M. Marquis, K.B. Averyt, M. Tignor, and H.L. Miller, Eds.). Cambridge University Press, Cambridge, $996 \mathrm{pp}$.

Jones P. D., M. New, D. E. Parker, S. Martin and I. G. Rigor, 1999. Surface air temperature and its changes over the past 150 years. Rev. Geophys. 37, 173-199, doi:10.1029/1999RG900002.

Jones P. D. and A. Moberg, 2003. Hemispheric and large-scale surface air temperature variations: An extensive revision and an update to 2001. J. Climate 16, 206-223.

Kilpatrick K. A., G. P. Podesta and R. Evans, 2001. Overview of the NOAA/NASA advanced very high resolution radiometer pathfinder algorithm for sea surface temperature and associated matchup database. J. Geophys. Res. 106, 9179-9197, doi:10.1029/ 1999JC000065.

Lejeusne C., P. Chevaldonné, C. Pergent-Martini, C. F. Boudouresque and T. Pérez, 2010. Climate change effects on a miniature ocean: The highly diverse, highly impacted Mediterranean Sea. Trends Ecol. Evol. 25, 250-260, doi:10.1016/j.tree.2009.10.009.

Lionello P., P. Malanotte-Rizzoli, R. Boscolo, P. Alpert, V. Artale, L. Li, J. Luterbacher, W. May, R. Trigo, M. Tsimplis, U. Ulbrich and E. Xoplaki, 2006. The Mediterranean climate: An overview of the main characteristics and issues. In: Mediterranean climate variability (P. Lionello, P. Malanotte-Rizzoli and $\mathrm{R}$. Boscolo, Eds.). Elsevier, Amsterdam, 1-26.

López García M. J., 1991. La temperatura superficial del mar Balear a partir de imágenes de satélite. Universitat de València, 158 pp.

López García M. J., C. Millot, J. Font and E. GarcíaLadona, 1994. Surface circulation variability in the Balearic Basin. J. Geophys. Res. 99, 3285-3296, doi:10.1029/93JC02114.

López García M. J. and A. M. Camarasa Belmonte, 2011. Recent trends of SST in the Western Mediterranean basins from AVHRR Pathfinder data (1985-2007). Global Planet. Change 78, 127-136, doi:10.1016/j. gloplacha.2011.06.001.

Macías D., E. García-Gorriz and A. Stips, 2013. Understanding the causes of recent warming of Mediterranean waters. How much could be attributed to climate change? Plos ONE 8, e81591, doi:10.1371/journal. pone.00811591.

Marullo S., B. Buongiorno, M. Guarracino and R. Santoleri, 2007. Observing the Mediterranean Sea from space: 21 years of Pathfinder-AVHRR sea surface temperatures (1985 to 2005): Re-analysis and validation. Ocean Science 3, 299-310.

Millot C., 1999. Circulation in the western Mediterranean Sea. J. Mar. Syst. 20, 423-442, doi:10.1016/s09247963(98)00078-5. 
Morales C. G., M. T. Ortega, J. L. Labajo and A. Piorno, 2005. Recent trends and temporal behavior of thermal variables in the region of Castilla-León (Spain). Atmósfera 18, 71-90.

Nykjaer L., 2009. Mediterranean Sea surface warming 1985-2006. Climate Res. 39, 11-17, doi:10.3354/ cr00794.

Palmer M. D., K. Haines, S. F. B. Tett, and T. J. Ansell, 2007. Isolating the signal of ocean global warming. Geophys. Res. Lett. 34, L23610, doi:10.1029/2007GL031712.

Rayner, N. A., P. Brohan, D. E. Parker, C. K. Folland, J. J. Kennedy, M. Vanicek, T. J. Ansell and S. F. B. Tett, 2006. Improved analyses of changes and uncertainties in sea surface temperature measured in situ since the mid-nineteenth century: The HadSST2 dataset. J. Clim. 19, 446-469, doi:10.1175/JCLI3637.1

Rholing E. J. and H. Bryden, 1992. Man-induced salinity and temperature increases in the western Mediterranean deep water. J. Geophys. Res. 97, 11191-11198, doi:10.1029/92JC00767.

Salat J. and J. Pascual, 2006. Principales tendencias climatológicas en el Mediterráneo noroccidental, a partir de más de 30 años de observaciones oceanográficas y meteorológicas en la costa catalana. In: Clima, sociedad y medio ambiente (J. M. Cuadrat, M. A. Saz, S. M. Vicente Serrano, S. Lanjeri, M. de Luis and J. C. González-Hidalgo, Eds.). Asociación Española de Climatología, Zaragoza, 283-290.

Serra C., A. Burgueño and X. Lana, 2001. Analysis of maximum and minimum daily temperatures recorded at Fabra Observatory (Barcelona NE Spain) in the period 1917-1998. Int. J. Climatol. 21, 617-636, doi:10.1002/ joc.633.

Scherrer S. C., M. A. Liniger and C. Appenzeller, 2008. Distribution changes of seasonal mean temperature in observations and climate change scenarios. In: Climate variability and extremes during the past 100 years (S. Brönnimann, J. Luterbacher, T. Ewen, H.F. Diaz, R.S. Stolarski and U. Neu, Eds.). Springer, 251-267.
Servain J., G. Caniaux, Y. K. Kouadio, M. J. McPhaden and M. Araujo, 2014. Recent climatic trends in the tropical Atlantic. Clim. Dyn. 43, 3071-3089, doi:10.1007/ s00382-014-2168-7.

Skliris N., S. Sofianos, A. Gkanasos, A. Mantziafou, V. Vervatis, P. Axaopoulos and A. Lascaratos, 2012. Decadal scale variability of sea surface temperature in the Mediterranean Sea in relation to atmospheric variability. Ocean Dynam. 62, 13-30, doi:10.1007/ s10236-011-0493-5.

Tzanatos E., D. E. Raitsos, G. Triantafyllou, S. Somarakis and A. A. Tsonis, 2014. Indications of a climate effect on Mediterranean fisheries. Climatic Change 122, 41-54.

Vargas-Yáñez M., J. Salat, M. L. Fernández, J. L. López-Jurado, J. Pascual, T. Ramírez, D. Cortés and I. Franco, 2005. Trends and time variability in the northern continental shelf of the western Mediterranean. J. Geophys. Res. 110, C10019, doi:10.1029/ 2004JC002799.

Vargas-Yánez M., M. J. García, J. Salat, M. C. GarcíaMartínez, J. Pascual and F. Moya, 2008. Warming trends and decadal variability in the Western Mediterranean shelf, Global Planet. Change 63, 177-184, doi:10.1016/j.gloplacha.2007.09.001.

Vargas-Yánez M., F. Moya, M. C. García-Martínez, E. Tel, P. Zunino, F. Plaza, J. Salat, J. Pascual, J. L. López-Jurado and M. Serra, 2010. Climate change in the western Mediterranean Sea 1900-2008. J. Mar. Syst. 82, 171-176, doi:10.1016/j.jmarsys.2010.04.013. Vázquez J., K. Perry and K. Kilpatrick, 1998. NOAA/ NASA AVHRR Oceans Pathfinder sea surface temperature data set user's reference manual, v-4.0. JPL Publication D-14070. Available at: https://www.nodc. noaa.gov/woce/woce_v3/wocedata_2/sat_sst/avhrr/ docs/usr_gde4_0_toc.htm. 